\title{
Dollarization in Sierra Leone: Evidence and Some Policy Options
}

\author{
Abu Bakarr TARAWALIE ${ }^{1} \&$ Amadu JALLOH ${ }^{2}$ \\ ${ }^{1}$ Lecturer at the Department of Economics and Commerce, Fourah Bay College, University of Sierra Leone \\ ${ }^{2}$ graduating student at the Department of Economics and Commerce, Fourah Bay College, University of Sierra Leone \\ Correspondence: Abu Bakarr TARAWALIE, Department of Economics and Commerce, Fourah Bay College, \\ University of Sierra Leone.
}

The views expressed in this paper are those of the authors and do not in any way represent the official position of the University of Sierra Leone.

Received: June 9, 2020

Accepted: June 28, 2020

Available online: June 29, 2020

doi:10.11114/aef.v7i4.4920

URL: https://doi.org/10.11114/aef.v7i4.4920

\begin{abstract}
This study aims to empirically investigate the determinants of dollarization in Sierra. It uses quarterly data from 1992Q1 to 2017Q4 and autoregressive distributed lag Bound Testing technique. Both the long and short run results revealed that inflation, exchange rate depreciation, financial deepening and war dummy were the main determinants of dollarization in Sierra Leone during the study period. The error correction term depicts that 53 percent of any disequilibrium in dollarization will be corrected within a year. A key policy recommendation is that policy makers should implement prudent policies that will ensure broader macroeconomic stability (including price stability and exchange rate stability) as a recipe for de-dollarization in Sierra Leone.
\end{abstract}

Keywords: dollarization, Sierra Leone, autoregressive distributed lag, quarterly data

JEL classification: E4, F31, F33

\section{Background}

Since the early 1990s, the concept of dollarization has been an important issue, especially in emerging market economies (Agénor \& Khan 1996; Yinusa \& Akinlo, 2008). The literature suggests that, persistent exchange rate volatility and rising inflation forced many developing countries into partial replacement of their domestic currencies with foreign currency. Deposit dollarization, defined broadly as the act of switching from holding domestic currency into holding foreign currencies by rational economic agents in bank accounts domiciled in domestic banks. The literature has identified three main types of dollarization: monetary dollarization or currency substitution - this involves the substitution of domestic currency with foreign currency; financial dollarization or asset dollarization - this involves holding of foreign currency assets and liabilities by the public; and real dollarization - this involves indexation of wages and real estate in foreign currency.

The empirical literature recognized various reasons why policy makers are worried about increased dollarization of an economy. Studies have shown that dollarization will affect an economy in several ways including among others the following: (i) reduce the yield of the "inflation tax" and results in higher and more volatile inflation,; (ii) monetary policy becomes ineffective, since it reduce the monetary authorities' control over domestic liquidity and rendering money demand less stable; (iii) affects the choice of exchange rate regime; and (iv) opportunities for seigniorage is reduced.

In Sierra Leone, the initiatives of policy makers and government have centred on creating a stable macroeconomic environment to boost growth and development. Following the end of the civil conflict, the government implemented prudent policies aimed at boosting economic growth and maintaining broader macroeconomic stability. However, notwithstanding government's effort to achieve macroeconomic stability, the Sierra Leone economy is epitomized by high inflation, persistent exchange rate volatility, surge in budget deficits, chronic balance of payment deficit, high public debt and debt servicing. Though US dollar is not officially a legal tender in Sierra Leone, yet it is widely used by both government and the private sector for business transactions, including payment for goods and services and settlement of debt. Most transactions are quoted in US dollars, and the black market for US dollar transaction is wide spread with little government control. The issue of dollarization in Sierra Leone stems from an endemic political 
instability and economic imbalances. The policy syndromes that necessitates dollarization in Sierra Leone includes; shallow financial system and limited financial deepening, political instability and civil unrest, high inflation, weak governance and inadequate institutional capacity, high budget deficit and public debt, poor infrastructure development, low development of the private sector, high cost of doing business, large informal sector, weak export base, and heavy reliance on import, which is reflected in high demand for foreign currency.

The concept of dollarization in Sierra Leone gained momentum in the early 1990s due to the dollarization of diamond transaction. In 1991, Sierra Leone issued the Public Notice No.8 granting permission for Diamond Exporters to officially use the US dollar to finance their diamond operations and to open customer foreign currency accounts at a commercial bank in Sierra Leone. As a result, Sierra Leone introduced a Customer Foreign Currency (CFC) accounts in 1992, that permits individuals and companies to operate Foreign Currency Accounts at commercial banks in Sierra Leone. Foreign currency accounts were to be used for the purpose of making payments abroad and in accordance with the regulations governing payments abroad for goods and services. Following the introduction of CFC in 1992 and the commencement of large scale mining activities by Sierra Rutile, the value of foreign currency account balances increased significantly due to the fact that, foreign currency held outside the official sector were deposited within the banking system, and exporters were given the opportunity to have free access to their funds for the payment of goods and services abroad. The foreign exchange market has three formal players; commercial banks, foreign exchange bureaus and the Central Bank of Sierra Leone. The Central Bank's intervention is to complement monetary policy operations, through weekly foreign exchange auction, albeit small. Sierra Leone currently operates a market determined exchange rate.

Analysis of the percentage distribution of foreign currency account balances by sectors is shown in Figure 1. The analysis shows that of the total foreign currency deposits held within the six largest commercial banks in Sierra Leone, government projects account balances represent the largest share of 39.6 percent. Foreign currency deposit by mining companies accounts for 16.9 percent, small and medium enterprises 14.7 percent, individual account holders represent 12.0 percent, development partners account balances represent 10.3 percent. Furthermore, Ministries, Department and Agencies (MDAs) account balances represent 3.1 percent, petroleum companies account for 0.2 percent of total foreign currency deposit, telecom companies account balances represent 0.1 percent, whilst airlines/Sea transport operators account balances represent 3.1 percent of total foreign currency deposit.

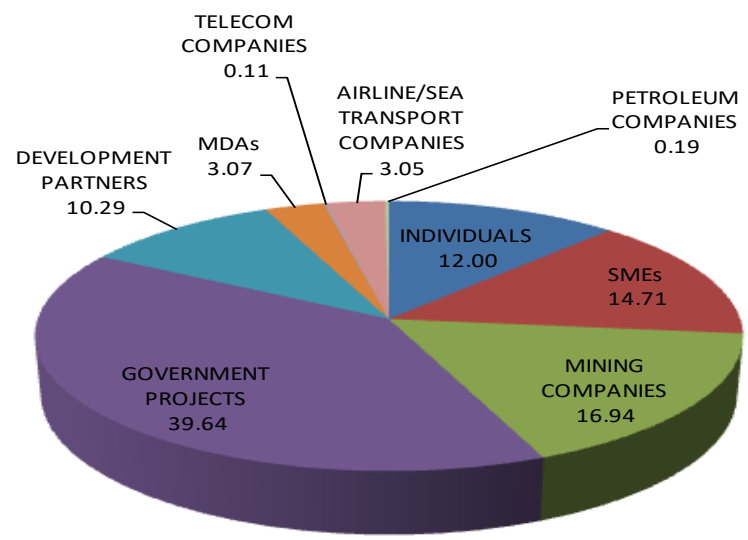

Figure 1. Foreign Currency balances by sector

\section{Source: Authors compilation}

Deposit dollarization as a percent of total deposit has been on the increase since the introduction of the customer foreign currency account in the early 1990s. As evident from Figure 2, deposit dollarization as a percent of total deposit increased to 43 percent in 2007 from 37 percent in 2002, but decline in 2008. The high level of dollarization in 2006 and 2007 was partly due to macroeconomic imbalances (including high inflation, exchange rate depreciation, low export earnings and high public debt) and political instability following the conduct of presidential elections in 2007. However, the decline in deposit dollarization in 2008 could partly be explained by the slowdown in economic activity including low GDP growth, low FDI inflows, drop in tourism, and low export earnings during the global financial crisis. Deposit dollarization as a percent of total deposit averaged 40 percent during the period under review. It is evident from the analysis that dollarization remains a key challenge in Sierra Leone and the key drivers of dollarization requires adequate attention. 




Figure 2. Deposit Dollarization in Sierra Leone

Source: Authors compilation

Despite recent development of banking activities, Sierra Leone's financial sector remains small, comprising 14 commercial banks offering a limited range of financial instruments. The financial system is shallow and provides limited opportunities for saving in local currency. Furthermore, the economy is characterized by limited monetization, less diversified export sector, low savings rate, heavy reliant on imports, persistent exchange rate volatility and episodes of high inflationary pressure. As a result, people prefer holding their assets in foreign currencies, whilst the country also experience high capital outflow as investors hedge against exchange rate risk. In a press release (Bank of Sierra Leone press release on the $15^{\text {th }}$ September, 2019), the Governor urged the private sector to conduct all domestic transactions in local currency - the leone. He requested all hotels and airline operators to transact in the local currency and also asked landlords to lease their premises in local currency as against foreign currency. The aim of such a policy is to mitigate the persistent depreciation and discourage dollarization.

Sierra Leone is a member of the West African Monetary Zone (WAMZ) programme, whose objective is to form a monetary union that is akin to the European Monetary Union. One of the requirements for the establishment of the WAMZ monetary union is the achievement of the exchange rate stability criterion by all its members - i.e. countries are required to maintain the WAMZ exchange rate mechanism (ERM) central parity ratei and fluctuate within a band of +15 percent. Satisfying this criterion remains a challenge for the country, as the rate of deprecation has always been above the \pm 15 percent threshold. The high depreciation continues to trigger a situation where people prefer holding their wealth in foreign denominated assets, there by intensifying dollarization in Sierra Leone.

The aim of this paper is to empirically investigates the determinants of dollarization in Sierra Leone, a small open economy in fragility. This study contributes to the existing literature in the following ways: Firstly, despite the abundant literature, the researchers are not aware of any country-specific empirical research work that has been done for Sierra Leone. This study remains the first country-specific research work that seeks to identify the drivers of dollarization in Sierra Leone. Furthermore, this study utilizes the autoregressive distributed lag modelling technique to establish key determinants of dollarization. The rest of the paper is organized as follows: Section 2 provides the literature review, which includes the theoretical and empirical. Section 3 focuses on the methodology. Section 4 presents the empirical analysis, and section 5 provides the conclusion and policy recommendations.

\section{Literature Review}

The theoretical literature on dollarization has identified four models including; currency substitution theory, portfolio theory, market failure theory, and the institutional theory. The main thrust of the currency substitution theory is that, increase in prices and depreciation of the exchange rate will reduce the real value of financial assets. As such economic agent will prefer holding assets in foreign currency. The theory requires economic agents to hedge against the risks associated with the erosion of purchasing power occasioned by the weakening macroeconomic fundamentals. For instance, an increase in inflation or depreciation of the domestic currency will reduce the purchasing power of the local currency. As a result, economic agents will substitute local currency in favour of the foreign currency. Thus, prevalence of macroeconomic instability in an economy will intensify dollarization and encourage capital flight. The institutional view highlights how the commitment of policymakers to build stable exchange rates creates dollarization. In their quest to maintain a stable exchange rate, policy makers places more premium in building their credibility on a stable exchange rate without taking into consideration the establishment of strong institutional framework to boost confidence in domestic currency holding. Weak institutional framework increases dollarization and the costs associated with exchange rate depreciation (De Nicolo, et al., 2005). The theory suggests that the quality of institutions might enhance or dampen factors that drives dollarization. 
The portfolio view explains dollarization as the optimal portfolio choice for a given distribution of real returns in each currency (Ize \& Levy Yeyati, 2003). The approach suggests that, if the returns on foreign currency deposit is higher than local currency deposit, then deposit dollarization will be higher. The theory assumes the validity of the uncovered interest rate parity, such that an increase in the variance of domestic inflation relative to the variance of real currency depreciation induces dollarization as the domestic currency becomes unattractive. This theory asserts that risk-averse resident investors seek to optimize the gains in the determination of asset portfolio. Thus, while the real return on assets denominated in local currency is influenced by variations in inflation, the real return on asset denominated in foreign currency is determined by fluctuations in real exchange rate. Advocates of market failure view considers dollarization as a consequences of market imperfections. This theory asserts that, dollarization exists due to the presence of market imperfections and externalities, and the lack of adequate regulatory framework. According to this theory, market failure arises as a result of restrictions in the use of foreign currencies, due to limited current account openness and weak financial sector. The existence of these factors may affect the dynamics of dollarization. The market failure theory postulates the relationship between dollarization and the extent to which economic agents have access to foreign currency for financial intermediation. It asserts that financial dollarization increases when agents can easily access foreign currency denominated credit facilities without regard for the risks emanating from currency depreciation.

The empirical literature on dollarization has produced mixed results. Some studies noted that inflation, exchange rate depreciation, low export are the key determinants of dollarization. Other researchers find political instability, interest rate and market developments as the major determinants of dollarization. Kessy (2011) investigates the determinants of financial dollarization in Tanzania using an error-correction framework. The results establish an inverse relationship between dollarization and inflation. Using Turkish data for the period 1986:1 to 1999:12, Civcir (2003) explains dollarization with an extended portfolio model. The results show that interest rate differential and expected exchange rates are the drivers of dollarization. In a related study, Metin-Ozcan \& Us (2007) investigates the determinants of dollarization in Turkey. Using a VAR model, the findings reveal that exchange rate depreciation and inflation are the main cause of dollarization.

Mecagni et al. (2015) investigates the determinant of dollarization and de-dollarization using panel data for selected SSA countries. They utilize both loan and deposit dollarization as dependent variables. The results indicate that inflation and exchange rate depreciation are the main determinants of dollarization. Similarly, Corrales et al. (2016) estimate the determinants of dollarization for 60 SSA countries. Their findings show that inflation and market development features are the determinants of dollarization. Raheem \& Asongu (2016) investigates the determinants of dollarization for 26 SSA countries. Using a Tobit regression model, the findings suggest that dollarization is largely driven by inflation, trade openness, and financial integration. In a related study, Yinusa (2009) examines the drivers of dollarization for 18 SSA countries, within the standard money demand model. The results reveal that inflation and exchange rate are the main drivers of dollarization.

Neanidis \& Savva (2009) examines the determinant of financial dollarization using an unbalanced panel for 11 transition economies, from 1993:2 to 2006:12. The findings show that dollarization is largely influenced by exchange rate, international financial integration, and institutional quality. Elkhafif (2003) examines the dynamic of the currency substitution in Egypt and South Africa within an error-correction model. The results indicate that exchange rate is a key determinant of dollarization.

The empirical literature is inconclusive in determining the drivers of dollarization. Few research works identify inflation, exchange rate depreciation and trade openness as the key determinants of dollarization. Others suggest political instability, market developments, per capita GDP as the major determinants of dollarization. Thus, a study that seeks to identify the major determinants of dollarization in Sierra Leone will provide a framework that will highlight the key drivers of dollarization in a fragile economy. It will also guide the monetary authorities on the design of an appropriate exchange rate policy, and measure for de-dollarization.

\section{Methodology}

To better identify the drivers of dollarization in Sierra Leone, we utilizes the autoregressive distributed lag (ARDL) model developed by Pesaran \& Shin (1998). The choice of the ARDL model is that it is applicable regardless of the order of integration of the variables. It can be used for $\mathrm{I}(0)$ or $\mathrm{I}(1)$ variables, or a mixture of both. Furthermore, the ARDL is applicable for estimating both the long and short run simultaneously.

The model developed in this research work is derived from existing theoretical and empirical foundation. It is also based on the structure of the Sierra Leone economy. The model builds on existing model developed by De Nicolo et al. (2005) and Kokenyne et al. (2010). This study specified the following model:

$$
\ln D D_{t}=\beta_{0}+\beta_{1} \operatorname{lncpi}_{t}+\beta_{2} \ln E R_{t}+\beta_{3} \operatorname{lnFin}_{t}+\beta_{4} \ln Y_{t}+\beta_{5} \operatorname{lnFDI} t+\lambda D u m+\mu_{t}
$$


Where $\operatorname{lnDD}$ is $\log$ of deposit dollarization (i.e. foreign currency deposit as a share of total deposit); lnCPI represent inflation, $\operatorname{lnER}$ is nominal effective exchange rate; $\operatorname{lnFin}$ is financial indicator (representing financial deepening. Defined as the ratio of money supply to GDP); $\ln Y$ is $\log$ of GDP per capita, and lnFDI is ratio of foreign currency inflow to GDP, (proxy by FDI/GDP) and Dum is the war dummy- which range between zero and 1, i.e. 1 for war period and zero for peace. Independent variables are all lagged to account for possible delayed effects. $\beta_{0}$ represent intercept, $\beta_{\mathrm{i}}$ represent parameter estimates, $\lambda$ is dummy coefficient, $\mu_{t}$ is error term, and $t$ represent time.

To enable us establish whether the variables are cointegrated, we specified an unrestricted ARDL model of dollarization and its determinants as follows;

$$
\begin{gathered}
\Delta \ln D D_{t}=\beta_{0}+\sum_{i=1}^{p} \beta_{1} \Delta \operatorname{lncpi}_{t-1}+\sum_{i=1}^{r} \beta_{2} \Delta \ln E R_{t-1}+\sum_{i=1}^{s} \beta_{3} \Delta \operatorname{lnfin} \ln _{t-1}+\sum_{i=1}^{u} \beta_{4} \Delta \ln Y_{t-1}+\sum_{i=1}^{v} \beta_{5} \Delta \ln F D I_{t-1}+ \\
\alpha_{1} \ln D D_{t-j}+\alpha_{2} \operatorname{lncpi}_{t-j}+\alpha_{3} \ln E R_{t-j}+\alpha_{4} \ln F i n_{t-j}+\alpha_{5} \ln Y_{t-j}+\alpha_{6} \ln F D I_{t-j}+\lambda D u m+\mu_{t}
\end{gathered}
$$

The $\Delta$ represent first difference, $\mathrm{p}, \mathrm{r} \& \mathrm{~s}$ are the optimal lag length, $\beta \& \alpha$ are parameter estimates. To test for co-integration, we proceed by computing the F-statistic from equation (2). The literature suggests that, the null hypothesis assume there is no co-integration, hence we restrict the lagged values of all the variables in levels to zero (i.e. $\left.\alpha_{1=} \alpha_{2=} \alpha_{3=} \alpha_{4=} \alpha_{5=} \alpha_{6=0}\right)$, and the alternative hypothesis that they are not equal to zero $\left(\alpha_{1} \neq \alpha_{2} \neq \alpha_{3} \neq \alpha_{4} \neq \alpha_{5} \neq \alpha\right.$ $\left.{ }_{6} \neq 0\right)$. The literature generates two sets of critical values - i.e. I(1) series, which is the upper bound critical values and $\mathrm{I}(0)$ series, the lower bound critical values. If the computed F-statistic is greater than upper bound values, we conclude there is cointegration. Also, if the computed F-statistic is below the lower critical value, we conclude there is no cointegration.

If the result confirmed the existence of cointegration, we proceed to estimate a restricted ARDL error correction model representation of equation 2 , as follows:

$$
\begin{aligned}
& \Delta \ln D D_{t}=\beta_{0}+\sum_{i=1}^{p} \beta_{1} \Delta \operatorname{lncpi}_{t-i}+\sum_{i=1}^{r} \beta_{2} \Delta \ln E R_{t-i}+\sum_{i=1}^{s} \beta_{3} \Delta \operatorname{lnFin}_{t-i}+\sum_{i=1}^{u} \beta_{4} \Delta \ln Y_{t-i}+\sum_{i=1}^{v} \beta_{5} \Delta \ln F D I_{t-i}+ \\
& \lambda D u m+\delta E C T_{t-1}+\mu_{t}
\end{aligned}
$$

Where $\beta_{\mathrm{i}}$ 's are short run coefficients, $\delta$ represent the speed of adjustment.

The error correction term $\left(\mathrm{ECT}_{\mathrm{t}-1}\right)$ is specified as:

$$
\begin{aligned}
& E C T_{t}= \\
& L n D D_{t}-\beta_{0}-\sum_{i=1}^{p} \beta_{1} \Delta \operatorname{lncpi} i_{t-i}-\sum_{i=1}^{r} \beta_{2} \Delta \ln E R_{t-i}-\sum_{i=1}^{s} \beta_{3} \Delta \ln F i n_{t-i}-\sum_{i=1}^{u} \beta_{4} \Delta \ln Y_{t-i}-\sum_{i=1}^{v} \beta_{5} \Delta \ln F D I_{t-i}-
\end{aligned}
$$

$\lambda D u m$

The study used the cumulative sum of recursive residuals (CUSUM) and cumulative sum of squares of recursive residuals (CUSUMSQ) to test for the stability of the model. If CUSUM and CUSUMSQ lies within the acceptable confidence interval, we conclude that the regression model is stable. The R-square and adjusted R-square tests are used to test to what extend the independent variables will help to explain variation in the dependent variable. Quarterly data from 1992Q1 to 2017Q4, obtained from Bank of Sierra Leone data base and International Financial Statistics Yearbook were used in the study.

\section{Presentation and Discussion of Results}

\subsection{Unit Root Test}

The study carried out the unit root test to ascertain the stationarity of the variables. The Augmented Dickey Fuller (ADF) and Philips Perron (PP) tests were used. The results indicate that all the variables in levels were non-stationary. However, all the variables in their first differenced were stationary, suggesting that all the variables are I(1) series.

Table 1. Stationarity test results

\begin{tabular}{|l|l|l|l|l|l|}
\hline Variables & \multicolumn{2}{l}{ Augmented Dickey-Fuller } & \multicolumn{2}{l|}{ Philips-Perron } & Order of Integration \\
\hline & Level & First Difference & Level & First Difference & \\
\hline DD & -2.4977 & -8.8105 & -2.4510 & -8.9582 & I (1) \\
\hline CPI & -2.2928 & -5.6516 & -2.0727 & -3.7706 & I (1) \\
\hline FDI & -2.0335 & -7.8108 & -2.1162 & -7.8108 & I (1) \\
\hline FIN & -2.4501 & -8.2243 & -2.324 & -8.0241 & I (1) \\
\hline GDP & -1.9501 & -8.3407 & -1.9539 & -8.3407 & I (1) \\
\hline ER & -2.1545 & -8.6782 & -2.1776 & -8.6782 & I (1) \\
\hline \multicolumn{7}{|l}{ Critical Values: $1 \%=-3.54,5 \%=-2.90$} \\
\hline
\end{tabular}

Source: Authors computation using Eviews 10. 


\subsection{ARDL Bound Test Results for Cointegration}

Haven established the order of integration of the variables, we conduct cointegration test. The null hypothesis $\left(\mathrm{H}_{0}\right)$ assumes no cointegration, whilst the alternative hypothesis $\left(\mathrm{H}_{1}\right)$ assumes there is cointegration. The rule of thumb is that, if the F-statistic is greater than both $1 \%$ and $5 \%$ upper bounds, then we conclude by rejecting the null hypothesis. The result of the cointegration test in Table 2, indicates that the F-statistics value of 6.65 is greater than 4.68 and 3.79, at the $1 \%$ and $5 \%$, respectively. We therefore conclude there is cointegration.

Table 2. Bound test result cointegration result

\begin{tabular}{|lcccc|}
\hline Test statistic & Value & Significance & I (0) & I (1) \\
\hline Asymptotic: $\mathrm{n}=1000$ & 6.6543 & $10 \%$ & 2.26 & 3.35 \\
F-Stat & 6 & $5 \%$ & 2.62 & 3.79 \\
K & & $2.5 \%$ & 2.96 & 4.18 \\
& & $1 \%$ & 3.41 & 4.68 \\
\hline
\end{tabular}

Source: Authors computation using Eviews 10

\subsection{Long Run Analysis}

Given that the variables are cointegrated, we proceed to estimate the long run model. The result is presented in Table 3. The result shows that an increase in inflation by one percentage point, will increase level of dollarization by 0.2 percent. This result bodes well for the Sierra Leone economy characterized by inflationary episodes, as inflation rate remains in double digit. Similar result was obtained by Yinusa (2009). Intuitively, inflation reduces the value of the domestic currency, which therefore urge people to hold more of foreign currency, therefore increase the level of dollarization.

Furthermore, analysis of the long run result reveals that a one percentage depreciation will increase dollarization by 0.07 percent. This result is not surprising for Sierra Leone, a small open economy typified by persistent depreciation. Similar result was obtained by Arango \& Nadiri (1981). Depreciation will reduce the value of assets denominated in domestic currency. As a result,people will prefer to hold their assets in foreign currency to avoid capital loss, thereby increasing the level of dollarization.

The finding also confirms an inverse relationship between financial deepening and dollarization. Decrease in financial deepening by one percentage point increases dollarization by 0.3 percent. A plausible reason for this result is largely due to the fact that the financial system in Sierra Leone is shallow and weak. Majority of the commercial banks have foreign ownership, and innovations in financial sector products and services are limited. Hence most people hold their assets in foreign currency, since there are limited products on offer by the financial sector, which tend to limit investment by economic agents.

Finally, the result shows a positive relationship between the war dummy and dollarization. The prevalence of political instability owing to the prolong civil war created uncertainty. As a result, most people fled the country and also caused huge capital outflow as investors prefer to invest in a more stable economy. This in turn created huge demand for foreign currency, and consequently increase the level of dollarization.

Table 3. ARDL Long run Coefficient estimates $(4,5,4,4,4,4)$

\begin{tabular}{|l|l|l|l|l|}
\hline variable & coefficient & Std. error & t-statistic & Prob. \\
\hline $\operatorname{lnCPI}$ & 0.2477 & 0.0790 & 3.1352 & 0.0028 \\
\hline $\ln$ ER & 0.0666 & 0.0272 & 2.4485 & 0.0233 \\
\hline $\ln$ FIN & -0.2761 & 0.1212 & -2.2781 & 0.0301 \\
\hline $\ln Y$ & -0.4532 & 0.3678 & -1.2321 & 0.4539 \\
\hline $\ln F D I$ & 0.0016 & 0.0008 & 1.8827 & 0.0650 \\
\hline Dum & 0.0152 & 0.0045 & 3.3778 & 0.0002 \\
\hline C & 15.5254 & 9.0021 & 1.7246 & 0.0902 \\
\hline
\end{tabular}

Source: Authors computation using Eviews 10

\subsection{Short Run Error Correction Model}

The short-run estimation results as presented in Table 4 suggest that deposit dollarization is largely influenced by inflation and exchange rate depreciation. Thus, the short run-dynamics result concur with the long run estimates. A one 
percent increase in inflation, increases dollarization by 0.3 percent, whilst a one percentage depreciation of the exchange rate will increase dollarization by 0.06 percent. Furthermore, with a coefficient of -0.53 , the estimates suggest a high speed of adjustment of dollarization to its long run equilibrium. Also, 62 percent of the variation in dollarization is accounted for by the explanatory variables, whilst F-statistics shows that the model is statistically significant.

Table 4. ARDL Short run error correction estimates $(4,5,4,4,4,4)$

\begin{tabular}{|c|c|c|c|c|}
\hline Variable & coefficient & Std. error & t-statistic & prob \\
\hline $\mathrm{C}$ & 15.5254 & 3.1739 & 4.8916 & 0.0000 \\
\hline $\mathrm{D}(\mathrm{CPI})$ & 0.2521 & 0.0743 & 3.3930 & 0.0002 \\
\hline $\mathrm{D}(\mathrm{ER})$ & 0.0598 & 0.0152 & 3.9342 & 0.0000 \\
\hline ECT(-1) & -0.5342 & 0.1162 & -4.5972 & 0.0000 \\
\hline R-squared & & Adjuste & 0.5123 & \\
\hline
\end{tabular}

Source: Authors computation using Eviews 10

\subsection{Stability Test}

We performed the cumulative sum of recursive residuals (CUSUM) and cumulative sum of squares of recursive residuals (CUSUMSQ) tests as popularized by Pesaran \& Pesaran (1997). The results as shown in Figures $3 \& 4$, indicate that the plots of CUSUM and CUSUMSQ for the estimated ARDL model lies within the acceptable limit of 5\% significance level. This indicates that the coefficients are stable.

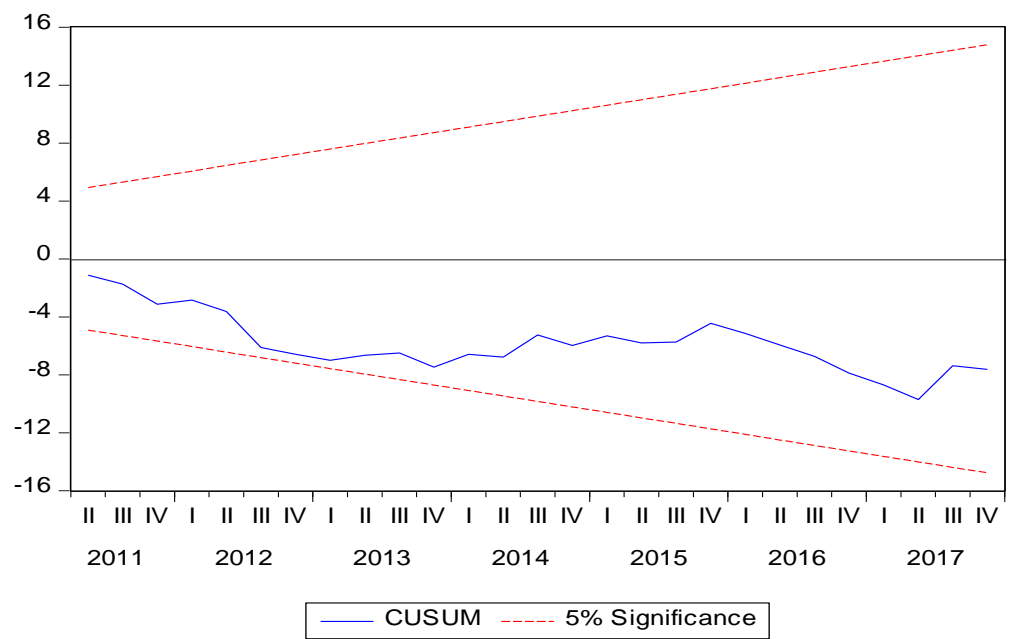

Figure 3. Result of CUSUM test for stability



Figure 4. Result of CUSUM of squares test for stability 


\section{Conclusion and Policy Recommendations}

The objective of this paper was to empirically investigate the main determinants of dollarization in Sierra Leone. The paper utilized quarterly data from 1992Q1 to 2017Q4 and adopted the ARDL Bound testing estimation framework.

The long run results showed that inflation, exchange rate depreciation, financial deepening and war dummy were the main determinants of dollarization in Sierra Leone during the study period. The results revealed that inflation, exchange rate depreciation and war dummy had positive impact on dollarization, whilst a negative relationship was established between financial deepening and dollarization. The short run results showed that inflation and exchange rate depreciation were the main drivers of dollarization in Sierra Leone during the study period. The error correction term indicated that 53 percent of the disequilibrium in dollarization is corrected within a year, whilst the F-statistics signaled that the model is statistically significant.

The policy implication of this study is that, in order to address the issue of dollarization, the government and policy makers should implement prudent monetary policy that will help maintain price stability. Thus, achieving a broader macroeconomic stability is a recipe for de-dollarization in Sierra Leone. Also, central bank financing of government budget deficit should be maintained within the accepted limit of not more than 5\% of previous year tax revenue in order to help curb inflationary pressure. Furthermore, there is a need to strengthen the export sector in order to boost export earnings and increase foreign currency inflows. There is also a need to deepen the financial sector by introducing more products and services to ensure economic agents diversify their portfolio investments. Finally, there is a need for government to maintain political stability in order to provide the ambiance for investors to thrive.

\section{References}

Agenor, P. R., \& Khan, M. S. (1996). Foreign currency deposits and the demand for money in developing countries. Journal of Development Economics, 50(1), 101-118. https://doi.org/10.1016/0304-3878(96)00005-3

Arango, S., \& Nadiri, M. (1981). Demand for Money in Open Economies. Journal of Monetary Economics, 7(1), 69-83. https://doi.org/10.1016/0304-3932(81)90052-0

Berg, A., \& Borensztein, E. (2000). The Dollarization Debate. Finance and Development, 37(1), 38-41. https://doi.org/10.5089/9781451846966.001

Civcir, I. (2003). Money demand, financial liberalization and currency substitution in Turkey. Journal of Economic Studies, 30(5), 514-534. https://doi.org/10.1108/01443580310492817

De Nicoló, G., Honohan, P., \& Ize, A., (2005). Dollarization of bank deposits: causes and consequences. Journal of Banking and Finance, 29(7), 1697-1727. https://doi.org/10.1016/j.jbankfin.2004.06.033

Elkhafif, M. A. T. (2003). Exchange rate policy and currency substitution: The case of Africa's emerging economies. African Development Review, 15(1), 1-11. https://doi.org/10.1111/1467-8268.00058

IMF (2005). Dollarization in Sub-Saharan Africa Experience and Lessons. African Department Working Paper series, IMF Staff Papers, 39, 318-44, Washington.

Ize, A., \& Levy-Yeyati, E. (2003). Financial Dollarization, Journal of International Economics, 59(2003), 323-347. https://doi.org/10.1016/S0022-1996(02)00017-X

Juan-Sebastian, C. J., Patrick, A., Imam, P. A., Weber, S., \& Yehoue, E. (2016). Dollarization in sub-Saharan Africa. Journal of African Economies, 25(1), 28-54

Kessy, P. (2011). Dollarization in Tanzania: empirical evidence and cross-country experience, International Growth Centre Working Paper 11/0251, International Monetary Fund, Washington.

Kokenyne, A., Ley, J., \& Veyrune R. (2010). De-dollarization. IMF Working Paper/10/188. https://doi.org/10.5089/9781455202225.001

Levy-Yeyati, E. (2006). Financial dollarization: evaluating the consequences. Economic Policy, 21(45), 61-118. https://doi.org/10.1111/j.1468-0327.2006.00154.x

Mecagni, M. et al (2015, April), "Dollarization in Sub-Saharan Africa: Experience and Lessons" Washington: International Monetary Fund.

Metin-Ozcan, K., \& Us, V. (2007). Dedollarization in Turkey after decades of dollarization: A myth or reality? Physica A, 385, 292-306. https://doi.org/10.1016/j.physa.2007.06.018

Neanidis K. C., \& Savva, C. S. (2009). Financial Dollarization: Short-Run Determinants in Transition Economies. Journal of Banking and Finance, 33(10), 1860-73. https://doi.org/10.1016/j.jbankfin.2009.04.017

Pesaran, M. H., \& Pesaran, B. (1997). Working with Microfit 4.0: Interactive Econometric Analysis. Oxford: Oxford 
University Press.

Peseran, M. H., \& Shin, Y. (1998). Generalized impulse response analysis in linear multivariate models. Econ. Lett., 58(1), 17-29. https://doi.org/10.1016/S0165-1765(97)00214-0

Raheem. I. D., \& Asongu, S. A. (2016). Extending the Determinants of Dollarization in Sub-Saharan Africa: The Role of Easy Access to Foreign Exchange Earnings. African Governance and Development Institute Working Paper, WP/16/033. https://doi.org/10.2139/ssrn.2838044

Reinhart, C. M., Rogoff, K. S., \& Savastano, M. A. (2003). Addicted to dollars. NBER Working Papers: 10015). Cambridge, Massachusetts. https://doi.org/10.3386/w10015

Rojas-Suarez, L. (1992). Currency Substitution and Inflation in Peru. Revista de Análisis Económico, 7(1), 153-176.

Yinusa, D. O. (2009). Macroeconomic Fluctuations and Deposit Dollarization in Sub-Saharan Africa: Evidence from Panel Data. MPRA Paper No. 16259, Munich.

Yinusa, D. O., \& Akinlo, A. E. (2008). Exchange Rate Volatility and the Extent of Currency Substitution in Nigeria, Indian Economic Review, 43(2), 161-181.

\section{Copyrights}

Copyright for this article is retained by the author(s), with first publication rights granted to the journal.

This is an open-access article distributed under the terms and conditions of the Creative Commons Attribution license which permits unrestricted use, distribution, and reproduction in any medium, provided the original work is properly cited. 